\title{
ONLINE SHOPPING BEHAVIOR IN THE PERSPECTIVE OF MARTIN HEIDEGGER'S TECHNOLOGICAL PHILOSOPHY
}

\begin{abstract}
The purpose of this study examined online shopping behavior in Surabaya by using a technological philosophical point of view. The research contributes on critical thinking about human life in the era of technology, especially in online shopping. Methodology: This research approach was qualitative, with the phenomenological method from Martin Heidegger. Research informants were obtained using a key person who already knew the living conditions around the analyzed location. The data collection method used systematic interviews. Findings: The results show that the nature of online shopping behavior is a form of framing shopping as it is. Moreover, the result of this study are expected to contribute critical thinking related to human life in the world of technology.
\end{abstract}

Keywords: Martin Heidegger, Philosophy of Technology, Online Shopping Behavior.

\section{INTRODUCTION}

Futurologist Alvin Tofler sees that there are lifestyle companies that shape people's lifestyles, this is shown by the symbols appearing in the mass media such as lifestyle television shows. Anyone who fails to maintain a modern lifestyle in a group will feel alone (loneliness) and alienation (Toffler, 1971). Online shopping is a modern lifestyle because it is an event that arises after the existence of information technology such as the internet. Online shopping is a different shopping activity compared to traditional shopping.

Shopping, according to Engel, is started from fulfillment specific needs. The activity of "shopping" refers to someone's natural action to get goods that are needed by exchanging an amount of money in exchange for these goods (Engel, 1994). Meanwhile, online shopping means a manifestation of technology in electronic marketing of goods (e-commerce), for example, internet malls, namely mall businesses on the internet. Ritzer states that in general online shopping can be seen no longer as shopping as a fulfillment

\footnotetext{
${ }^{1}$ Rifqi Khairul Anam, MA, Doctoral student at Gadjah Mada University, Yogyakarta, Indonesia; e-mail: rrifqi.khairul.a@gmail.com (corresponding author). ORCID: 0000-0003-4475-3242.

2 Misnal Munir, Dr, Faculty of Philosophy, Gadjah Mada University, Yogyakarta, Indonesia; e-mail: misnalmunir@ugm.ac.id. ORCID: 0000-0001-5453-9317.

${ }^{3}$ Protasius Hardono Hadi, Dr, Faculty of Philosophy, Gadjah Mada University, Yogyakarta, Indonesia; e-mail: protasiushardono@ gmail.com. ORCID: 0000-0002-2288-0921.
} 
of needs but shopping as a broad field in which forms of necessity are centrally arranged and controlled (Ritzer, 2006).

One of the problems that arises is excessive shopping behavior (compulsive buying). The reason for compulsive buying behavior is the change in the rapid flow of trends in online shopping activities, for example the headlines in online stores always change from time to time (Sang Hee, Yun Jung, 2014). Compulsive buying behavior is self-destructive shopping behavior, a shopping behavior based on the need to get out of feelings of anxiety and discomfort, so that they find comfort through shopping even though they create financial problems in a person (Sang Hee, Yun Jung, 2014).

Based on the paragraph above, the main problem of this research is the sociological argument that the internet in general and internet pages on the internet in particular produce inanition (Ritzer, 2006). The word "empty" (nihil) means meaningless, because the entire meaning space has been framed. For example in the phenomenon of online shopping, the meaning of shopping as a fulfillment of needs becomes a phenomenon of uncontrolled buying or compulsive buying because people forget the meaning of shopping and seek pleasure in shopping (Sang Hee, Yun Jung, 2014).

The point of view of this research is the philosophy of technology. According to Borgman (Borgman, 2005), Martin Heidegger's technological philosophy discusses the human condition in the technological era. The core of the technology philosophy is that modern technology is a tool to reveal nature and humans as resources used in the production process. The purpose of this study is to find out the nature of online shopping behavior through the perspective of Martin Heidegger's technology philosophy and to offer solutions to see technology in online shopping at the same time. The benefit of this research in general is that it contributes critical thinking about human life in the era of technology, especially in online shopping.

\section{METHODOLOGY}

This study used a qualitative research paradigm; it means that the concepts adopted refer to the qualities of research object such as values, meanings, and events with a qualitative approach (Kaelan, 2005). This study used a phenomenological method, which is a study of what is phenomenal in everyday life, namely: online shopping. Heidegger saw phenomenology working in everyday life to see meaning, based on the vision of phenomenology to read human's natural attitude in relation to the world around it (Heidegger, 1975). Heidegger's phenomenological method used the principle of ontological difference (ontological difference), which means that the difference between the existence of something (Being) and the entity itself (beings). Philosophical research is research to find the meaning of something and bring the meaning that is present to us as a whole possibility (Heidegger, 1975).

\subsection{Data Collection}

The primary sources of this research data are data from interviews with informants and Martin Heidegger's philosophical thinking literature. A research informant is someone who understands the information on the object of research as an actor and appoints other people who know the object of research (Bungin, 2008). Research informants in the study were determined by purposive sampling, namely data collection techniques that are tailored to 
the objectives of the study (Sugiyono, 2016). The informants in this study were 18 people who were residents of Surabaya city who were regular customers of online shops Surabaya.

The researcher obtained informants by using the key person method, namely people who know information about the object of research. Key person also provides clues about who can be interviewed in order to obtain information about the object of research (Bungin, 2008), key person is required to help the researcher find informants who are appropriate and help initiate interviews with informants. The seller (reseller) of goods through an online shop called Onlishop with the owner named Riandini Aprilia Utomo was the key person of this research.

\subsection{Data Collection Technique}

The data collection technique used in this study was interview, which used systematic interview. A systematic interview is an interview conducted in which the interviewer prepares a written guide on what to ask the informant. The meaning of the evidence from the interview results only shows the presence of what is at issue but not evidence that the essence of online shopping has been objectively grasped. "Evidence" is phenomenological is filling the identification of the purpose of a particular action (Heidegger, 1985).

\subsection{Data Analysis}

Data analysis in this research was conducted by using methodology elements as follows: 1. Understanding

Understanding is a way discovering something concerned. Understanding is a description (outline) of something familiar regarding a situation context. Understanding in the first place is not a way of knowing (mode of knowing) but rather already knowing in advance where a person says "I can" interpreting items as something. Interpretation is a form of disclosure (explication) of understanding, something that is already known in understanding and can be interpreted by someone called meaning (Heidegger, 1985).

2. Interpretation

Interpretation is an explication from understanding to see something as something. Understanding allows an interpretation that shows a relationship between the phenomenon and the meaning of the phenomenon. Interpretation gives meaning to something; it means that interpreting is looking for words from what a researcher thinks, so that the meaning can be understood by others (Heidegger, 1985).

3. Formal Indication (Formale Anzeigen)

The character of the concept in Martin Heidegger's method of phenomenology in particular is a formal indication. Heidegger says that if philosophy seeks a principle from something that is concrete, then giving definition at the principle level still bears reference to something concrete there. Thus, the concept of philosophy regarding phenomena is to determine (formal) but at the same time indicate when a certain phenomenon is used as a reference to say Yes, without claiming to be exactly representative for the whole situation (Heidegger, 2001).

\section{RESULT AND DISCUSSION}

\section{Online Shopping as a Shopping Framing}

The essence of modern technology is a way of revealing, but the way of disclosure of modern technology is setting-upon to reveal (Heidegger, 1977). Online shopping is 
a technology manifestation in shopping; it can be said as a possibility that online shopping is no longer in the context of shopping as meeting certain and urgent needs, being transformed into a shopping framing. The word "framing" in the context of online shopping is shopping for items that are originally a fulfillment of a need turned into items that are bought as necessities.

There are two compelling arguments that online shopping is a form of technological framing of shopping:

1. Ritzer says "non-objects" are being sold on internet sites. "Non-object" refers to the simplicity of an object that buyers can find quickly and easily. This makes it easier but at the same time frames humans in consumption. The internet is a place of consumption because of the ease of getting the desired item. The meaning of an object becomes disappeared because the object is purchased not as the owner needs but as part of series of advertisements offered by consumption sites (Ritzer, 2006).

This is in accordance with the wrong statement from one of the informants, Mrs. Mufadillah, who said that online shopping is more efficient but also makes buying unnecessary items, as she said as follows:

"I prefer online shopping because it is efficient and doesn't have to waste time on travel and money. It's different from offline shopping in stores and at malls. There must be free time first to select items.

"Do you really need the items you buy from online shopping? No, I buy it because I want it not a need, so there are many items that I don't really need are bought".

2. Baudrillard's argument regarding the counterfeit uses of an item. Baudrillard summarizes the counterfeit uses of an item with the word "gizmo". The word "gizmo" refers to an object losing its practical aspect which is transferred to a mental image; "mental image" refers to a dream object behind a real object. For example, modern tools such as communication tools become symbols to show their owner's prestige (Baudrillard, 2002).

The purpose of purchasing items on online shopping shows whether the item is purchased is a purchase of a gizmo item in online shopping behavior. Based on an interview with Ms. Ninik, it indicates that items purchased on online shopping sites have gizmo properties in them, as Ms. Ninik said below:

Do you often follow up-to-date fashion and trends, if a new item comes out, will you buy it, even though the old stuff is still worth wearing? Yes, because most of the items sold are updated and up-to-date, so there is a sense of pride and no shame; Do you have a consumptive style, meaning you buy goods in excess, and in a planned manner. For example, you always want to look up to date? Yes, including consumptive, because I like bag collections and mutually change bags. I am affected by a fashionable environment.

The researcher interpreted that according to Ms. Ninik's testimony, her daily life environment closes to fashionable people which influenced her to this lifestyle. Associated with items that are consumed as gizmo is a lifestyle that prioritizes the style of dress, will buy items with gizmo properties, the reason is that what is important for someone who buys goods is not for the purpose of practical use. For example, materials that are comfortable to wear and durable, but rather with the purpose of collecting clothes to make it look always up to date or following the development of a dress style, is actually what is purchased is not 
the practical use of the clothes but a mental image of the gizmo item, which is pride to always follow the development of the style of dress.

\section{The Dangers behind Technology in the Context of Online Shopping Behavior}

Based on the Martin Heidegger's thought, the researcher interpreted three dangers of forgetting to exist through framing technology in the context of online shopping.

1. Machination and Life Experience (Lived Experience).

Framing gives direction to the dominance of making and what Heidegger calls machination. The word "machination" means a complex and hidden plan to gain power or control (Heidegger, 1999). The dominance of Machination presses humans to have live experience so that they become spectators of what has just been produced and they are forced to feel uncivilized if they have not tried the new life experiences offered by machination (Heidegger, 1994). Evidence from online shopping behavior is a form of shopping machination which is shopping behavior in online shopping that is conducted by Mrs. Wempy Widya Tristiyanti said:

For me, shopping online is shopping that is very easy and fun and more practical in this modern era, especially for me who is an office worker. But there is also a downside, if there is an error in shopping.

Researcher interpreted it as living in an office environment that does not have much time to shop, so she makes online shopping as life experience that cannot be missed. This shows that online shopping brings shopping practicality amid the lack of time to shop and online shopping must be experienced to be able to practically shop online.

\section{Total Mobilization}

World "total mobilization" is used for the first time by Erns Junger to describe that in 1933, whole workers participated in one purpose, which is the workers' spirit (gestalt) to achieve German reformation. The workers and soldiers are expected to participate in the technological order to rule the world. In particular, "moving the whole" refers to the process of moving the whole resource through modern technology to produce war materials in order to win World War I (Zimmerman, 1990).

Kadokawa Haruki says total mobilization is no longer moving in the military area as it was when Nazi Hitler was in power, but the principle of "moving the whole" is currently in the media industry to direct the masses to use uniformity to move towards consumption. The media move the whole through words, sounds, and images so that the masses come to one unit, namely the unity of standing-serving consumption itself (Steinberg, 2017).

Based on the meaning of "moving the whole" above, online shopping makes the body and motivation move to actively consume. This is in accordance with the testimony of the key informant, Ms. Riandiny, as follows:

We need time to go department store. Meanwhile, online shopping is more practical and spends more money at an ATM. Because online shopping is very easy, practical and sometimes there are lots of promos and discounts for each buyer ... we are affected by the discounts given by the online shop so we want to shop continuously, because the goods are good and facetious.

Based on the testimony above, the researcher interpreted the direction of total movement in the case of online shopping as an impulse to consume offered by online shopping. The impetus that drives someone to actively shop is advertising, practically advertising in online 
shopping in the form of promos and discounts has the effect of moving someone's desire to actively consume even though they are not being aware of it.

\section{Standing Serving}

Standing reserve is the name for anything that is regulated through framing. Human frames anything real to stand to serve humans, but actually human does not master the framing, human instead stands to serve the framing itself (Heidegger, 1977). Compulsive shopping behavior is a form of embodiment of stand-serve technology in the case of online shopping behavior.

Compulsive shopping behavior is defined as a chronic condition, in which a person engages in repeated buying activities. A person who is compulsive shopping does not see what he will do with his groceries but the consuming activity itself. Shopping has turned into a necessity itself (Soedjatmiko, 2008). Compulsive shopping behavior is an embodiment of standing to serve, the reason is that through an online shopping frame that makes shopping easy, people forget the meaning of shopping as a fulfillment of needs and go deeper into the pleasure of shopping itself, the character of this behavior is to make purchases of goods repeatedly without thinking due to the purchase (Edward, 1993).

Compulsive shopping behavior caused by framing in online shopping can be seen from the interview with Mrs. Ika Lestari as follows:

Are you able to control your expenses in shopping online? If not, what are you doing to cover the spending deficit? I can't control it because I like shopping and I can't forbear when I see cheap price of clothes and lots of discounts. Sometimes I go into debt to cover this month's shortfall, because last month my spending was too costly.

\section{Philosophical Reflection}

\section{Science and Technology Form a Gigantic Framing}

One of the main arguments for philosophical reflection is that modern science and technology form gigantic framing. Science enables human as subjects and items (such as nature and life) is objectified to be calculated and planned through science, while to reveal something practically uses technology (Heidegger, 1999). Science and technology form relationships in terms of framing, so that everything is counted to be equal. (Heidegger, 1977).

What determines the nature of science in terms of technology is the methodology and procedures. The methodology is the principles of the way of research relating to individual item space (individual item-sphere). The scientific system lies in the solidarity of methodologies and procedures which are the way to behave (attitude) to get any objectivity at any time. What is remarkable about the scientific system is not the tightness with regard to the item space and its contents, but rather the mastery of research techniques that are in accordance with the methodology (Heidegger, 1977)

At this point, the tools of modern technology as framing meet science as a technical capacity (technicity). Modern science is preparing the way for framing. Modern science contains the seed of framing, that is, when science becomes research by planning and securing research results with rigorous procedures. Research then challenges forward to regulating nature, seeing nature as something that must be organized to stand-serve as an information system (Heidegger, 1977). Ultimately, the pervasive power of modern 
technology and science in the rules of framing forms the "giant" ("the gigantic") corresponding to industrial society to become dominant (Heidegger, 2005).

Science and technology form a "giant" ("the gigantic"). This meaning of "giant" refers to the dominance of quantity as quality. The phrase "quantity as quality" means, what in the most present meaning before someone is ignored and replaced, counted primarily as what is most commonly represented. (Heidegger, 1999). Currently, "giant" is no longer just a quantity based on calculations and understands the subject that represents the whole entity. The gigantic form of science and technology today lies in the gigantism of the publictness (Heidegger, 1999).

In the giants of science and technology, where everything is framed to say one item is the same. There is abandonment of Being, the word "abandonment of being" means what is present in front of someone is ignored, what deserves to be asked (question-worthiness) about the entity disappears (Heidegger, 1999), what can be made (make-ability) through machination (Heidegger, 1999). The result of the domination of machination in many areas of life is the epoch of total lack of questioning. The result is that every attempt to ask and say something that disturbs someone's heart becomes marginalized, replaced by what is safe in the view that has been generally accepted (public), this is abandonment of Being (Heidegger, 1999).

\section{Abandonment of Being}

The main argument of this section is the Abandonment of Being by science and technology. The abandonment of Being is the basis on which Nietzsche first recognized nihilism (Heidegger, 1999). The abandonment of Being by technology has correlation with the nature of technology. Technology is a way of disclosure, however, the way of expressing technology is not revealing as it is, but challenging to reveal and organize (set upon). For example, air as nitrogen mine, the earth as a coal mine (Heidegger, 1977).

On the other hand, modern science ignores Being through the desire to build theory due to the machination character in science. Those who are present before humans are challenged to be framed in a theory. Theory deals with presenting what is present to humans, with the character of the power to show (Heidegger, 1977). Modern science makes objectivity in accordance with the character of what is real, but what is real is presented according to a generally accepted theoretical frame, so that anyone who is present before a researcher must be ignored, to be in accordance with the theory. The theory secures the objectivity of research at all times; the space-time difference is ignored to satisfy the validity of the theory. Every new phenomenon that arises in the area of science is manipulated to fit into the theoretical wreck. In other words, science regulates what is real to achieve objectivity (Heidegger, 1977).

The abandonment of Being causes a person to lose the root (autochthony) in which he was formed. A person losing roots means they lose what is closest to him in his homeland. They are "homeless" because every hour of the day is bound by radio and television to feel uncommon, but in fact it is a realm of the imagination that offers a world without a world. This means that all forms of advertisements that are present on television, radio, and pictorial magazines are mastery of communication techniques to bring someone to forget the questions that are present (Heidegger, 1966). 


\section{The End of Philosophy}

Heidegger saw philosophy as having an end in the current century (present age). Philosophy ends means: philosophy as metaphysics has reached the highest end (consummation). Metaphysics is the thought of Being as a whole in one model. Metaphysics is representational thinking, Being as a whole is held in one principle (arche) in the word "is" ("is") (Heidegger, 1972).

Philosophy as metaphysics has reached its highest end (consummation). The highest end means the inevitable development of the fundamental power of metaphysics, the disguised power of "asking" to surface. The highest end of metaphysics means that the essence of metaphysics as valuative thinking has been present in the highest configuration through the metaphysics of will power (Heidegger \& Krell, 1987). The final configuration of metaphysics opens up the most extreme possibility to create, through the many ways of making and shaping Being in a variety of worldviews (Weltanschauungen). The development of science in the field of philosophical life increases the role of logic and semantics, philosophy turns into an empirical science about humans and "technology" makes humans to free their values so that humans and technology can establish a world based on fashion of making and shaping. Heidegger saw philosophy as being on the path of science, philosophy based on science based on scientific knowledge and scientific discoveries, philosophy is currently guided scientifically through what is called "cybernetics" (Heidegger, 1972).

The philosophy in cybernetics is in accordance with the human character as a social being. Cybernetics turned language into news exchange, and philosophy was transformed into a separate science that communicated among them. Philosophy then finds its place in the scientific attitude of socially active humans to regulate the totality of entities and position human positions. Socially active human character directs philosophy towards theory; "Theory" ("theory") here means: the arrangement of categories to describe the area of investigation, which will later be used as a working hypothesis of scientists. A cybernetics-based philosophy will interpret everything at a structural level in accordance with the rules of science. The end of philosophy is the triumph of the manipulation of the scientific-technological and social order arrangements of the modern world (Heidegger, 1972).

Philosophy ends in the current century, is in the scientific attitude, this is cybernetic. Philosophy with the character of science tries to interpret anything at the level of structure based on the rules of science; the rules of science based on the truth of what can be measured by the consequences of its application and brings the development of research. Scientific truth is equivalent to freeing the existence of a researcher; the interest of science is directed to the cybernetic function, namely the model and operation of calculative thinking but denying the meaning and where the meaning of something comes from something is. This is the character of technology in science (Heidegger, 1972).

\section{Back to the beginning}

Researchers interpret the essence of Heidegger's thought is to restore the relationship between philosophy and everyday life that was cut off since Plato divided the two worlds, namely the transcendental world and the apparent world, this was revealed in the 1919 war emergency semester lecture, namely: The Idea of Philosophy and the Problem of Worldview. Heidegger (Heidegger, 2008) states that the idea of philosophy as primordial science echoes the presence of questions about everyday life. Philosophy as a preliminary 
science brings natural life to the root level. A researcher has always been in a specific scientific problem context for him, it is something that is purely a motivational context in researching. Heidegger (2008) sees that at this point philosophy and science are intertwined as habits that indicate the existence of researchers. Every individual life of a researcher is the root of the world of life, which gives motivational value to how the researcher researches in his world environment.

Everyone, including researchers, artists, religious leaders, politicians has a different horizon of life. A researcher does not live in isolation, there is already an environmental world that underlies it and provides a research context for him, and he is not value free from it. The context of life is the original root of the spirit of research. The spirit of research can be found anywhere, including in special sciences (from biology to sociology), the original research spirit develops the life of the researcher to the deepest level and he lives in his work, this means a researcher (scientific man) who will actually develop and elevate the context. The life he experiences is not as a representative form of theory, but as a personally motivated contemplation of life. Only through this path, Being is present at the highest authenticity, as a way of existence for each researcher who maintains what is original his own (Heidegger, 2008).

According to Prometheus, philosophy seeks knowledge, but philosophical knowledge is contemplative knowledge. For the Greeks, this knowledge was not a kind of practical adaptation to theory nor was it a cultural item. Philosophy is the most original realization of a human's daily practice; philosophy is the most decisive center that binds a person to the people around him and the country (Heidegger, 2003).

Philosophy is inseparable from daily life; it is the beginning of philosophy. Early philosophy in the Greeks maintained a relationship with what is present in front of a person, the consequence is that the definition of truth as the accuracy of representing the unknown, truth is a disclosure (a-letheia), it keeps their minds from being uncertain, that is, it can be questioned. Questions are not a step to seek answers and gain knowledge, but questions are the highest form of knowing. Questions open up the ultimate power to reveal all essential items. However, after two and a half millennia, human beings change towards development, through Christian theology to the mathematical-technological way of thinking in the modern age, making what philosophy and science collide with each other for certainty, and getting away from essential questions in each of their scientific fields, replaced by a model that has been tested based on the power of formation by historical humans, or simply a model that has been recognized by many people (Heidegger, 2003).

Heidegger (2003) says that if the essence of philosophy lies in questioning, then a person must be ready to survive without guards in the midst of the uncertainty of the whole destiny, here the spirit of research resides, the word "spirit" is not empty intelligence, nor is the game of chaos in the rational mind, and more specifically the spirit is not the world of reason; the spirit is the beginning of harmony, knowing the firmness towards Being itself. The spirit is not shaped by culture, nor is it useful facts and values; the formation of the spirit is the most profound force retained in a person's heart so as to vibrate.

\section{CONCLUSIONS AND SUGGESTIONS}

There are two conclusions that can be drawn based on the problems raised related to the subject matter that has been carried out are as follows: First, considering Heidegger's thoughts regarding technology, researchers see online shopping as framing (enframing) 
shopping, meaning: online shopping is wrong one embodiment of technology in electronic marketing of goods (e-commerce). Second, based on Martin Heidegger's technological philosophy, researchers interpret three dangers of online shopping as the embodiment of technology in shopping, namely: first, the dominance of what can be made (machination) and the experience of living to always experience something new. Second, online shopping moves all people to actively consume advertisements. Third, humans stand to serve technology itself. In the context of online shopping behavior, compulsive shopping behavior is the manifestation of standing to serve which is caused by the framing of technology in shopping.

There are three philosophical suggestions from this research, namely: First, Heidegger specifically offers a review of the relationship with technological tools, one can still use technological tools in everyday life as usual. However, one needs to also free oneself the technological tools of being unaffected by one's core roots. One also needs to always be open to what is hidden in the technological tools. Both provide the possibility for a person to be able to survive in a different world as a whole, namely the world of technology.

Second, changing the way of thinking to take into account (calculative thinking) which, taking philosophy further away from disclosing the atmosphere of daily everyday life is replaced by meditative thinking (meditative thinking). To think deeply is to contemplate the meaning of something that is present in front of him and feel the meaning of that something as a whole.

Third, one needs to awaken a fundamental nature for philosophy. His nature to do philosophy means to actively ask what is the meaning of something that is present in front of him, this is related to the need for philosophy to start from the problems of everyday life that seem trivial.

\section{REFERENCES}

Baudrillard, J. (2002). The System of Object. London: Verso.

Borgman, A. (2005). Technology (H. Dreyfus, M. Wrathal, eds.). Victoria: Blackwell Publishing Ltd.

Bungin, B. (2008). Penelitian Kualitatif: Komunikasi, Ekonomi, Kebijakan Publik, Dan Ilmu Sosial Lainnya. Jakarta: Kencana Predana Media Group.

Edward, A. E. (1993). Development of a New Scale for Measuring Compulsive Buying Behaviour. "Journal Financial Councelling and Planning", 4(1).

Engel, F. J. (1994). Consumer Behavior. Illinois: Dryden Press.

Heidegger, M. (1966). Discourse on thinking (J. M. Anderso, E. H. Freund, eds.). New York: Harper \& Row Publishers.

(1972). Being and Time (Joan Stamboagh, ed.). London: Harper \& Row Publishers.

(1975). The Basics Problems Of Phenomenology (A. Hofstadter, ed.). Indiana University Press.

(1977). The Question Concerning Technology And Other Essays (W. Lovitt, ed.). New York: Harper \& Row Publishers.

— (1985). History of the Concept of Time Prolegomena (T. Kisiel, ed.). Indiana: University Press.

(1994). Basic Question Of Philosophy: Selected "Problems" of Logic (R. Rojcewicz, A. Schuwer, ed.). Indiana: Indiana University Press. 
_ (1999). Contributions to Philosophy (From Enowning) (P. Emad, K. Maly, eds.). Indiana University Press.

(2001). Phenomenological Interpretations of Aristotle (R. Rojcewicz, ed.). Indiana: University Press.

— (2003). Philosophical and Political Writing (Manfred Stassen, ed.). London: Continuum International Publishing Group.

(2005). Sojourns: The Journey to Greece (Suny Series in Contemporary Continental Philosophy). State University Of New York Press.

- (2008). Toward The Definition of Philosophy. New York: Continuum International Publishing Group.

Heidegger, M., Krell, D. F. (1987). Nietzsche. Vols. 3 and 4 (Vol. 3: The Will to Power as Knowledge and as Metaphysics; Vol. 4: Nihilism). New York: Harper \& Row Publishers.

Kaelan (2005). Metode Penelitian Kualitatif Bidang Filsafat. Yogyakarta: Paradigma.

Ritzer, G. (2006). Mengkonsumsi Kehampaan Di Era Globalisasi (Lucinda M. Lett, ed.). Yogyakarta: Penerbitan Universitas Atma Jaya.

Sang Hee, S., Yun Jung, C. (2014). Phases of Shopping Addiction Evidenced by Experiences of Compulsive Buyers. "Internation Journal Mental Health Addiction", 12(3).

Soedjatmiko, H. (2008). Saya Bebelanja Maka Saya Ada: Ketika Konsumsi dan Desain menjadi Gaya Hidup Konsumeris. Yogyakarta: Jalasutra.

Steinberg, M. (2017). Media Mix Mobilization: Social Mobilization and Yo-Kai Watch. "Animation", 12(3). DOI: 10.1177/1746847717739565.

Sugiyono (2016). Metode Penelitian dan Pengembangan (Research and Development/R\&D) [In:] Bandung: Alfabeta. DOI: 10.1016/j.drudis.2010.11.005.

Toffler, A. (1971). Future shock [In:] Science Education. New York: Bantam Books Inc. DOI: $10.1002 /$ sce. 3730560328 .

Zimmerman, M. E. (1990). Heidegger's confrontation with modernity. Indiana University Press.

DOI: $10.7862 / \mathrm{rz} .2021 . \mathrm{mmr} .14$

The text was submitted to the editorial office: July 2021.

The text was accepted for publication: September 2021. 
